\title{
The Impact of Training and Development on Managers Awareness of Crisis Management: The Case of Egyptian Hotels
}

\author{
Yasser Mahmoud Ashraf El Sayed Abd El Maaboud \\ EL Hussein Ali \\ Faculty of Tourism and Hotels, Fayoum University
}

\begin{abstract}
Training and Development are the most important strategic tool for enhancing employee performance. The main objective of this study is to examine the effectiveness of training and development on managers awareness of crisis management in three and four-star hotels in greater Cairo and Sharm El Sheikh. The descriptive research method was adopted for this study using four hundred valid questionnaires that were completed by selected hotels managers in three and four-star hotels in greater Cairo and Sharm El Sheikh using a simple random sampling technique. The data collected were analysed using descriptive statistics to represent the raw data in a meaningful manner. Obtained data were analysed using SPSS version 22.

The results show that a strong relationship exists between training and development and the managers awareness of crisis management.
\end{abstract}

Keywords: Training and Development, Crisis Management Plan (C.M.P.), head of departments (H.O.D.), Hotel, Egypt.

\section{Introduction}

The literature on crisis management in the hospitality industry has gone through significant developments in recent years. This was done due to the unfortunate circumstances in which many countries experienced different crises situations (Kovoor-Misra et al. ,2001).

Training plays a significant role in achieving organizational objectives by keeping in view the interest of employees and organizations (Alao, 2010). Training receives high importance as it improves the skills, capabilities, confidence, and competencies. Training includes 'soft' skills such as software training, management training (Bassanini, 2004).

Moreover, Hernandez, (2015) added that Certain jobs require training and documentation in order for an employee to successfully implement the minimum job requirements related to that position. Franklin et al., (2014) managers can develop their own crisis management programs. Examines different types of crises before making suggestions about what to do when a crisis strikes. Travel and tourism are a high-growth industry, forecasted to increase its total economic activity by $4 \%$ worldwide in real terms over the next 10 years (WTTC, 2018).

The crisis in the Egyptian hospitality industry (2011-2018) and the Egyptian economy as a whole originates primarily from the instability of the Egyptian revolution 2011 and its adherents and also the instability in most of the other Arabic countries regarding their revolutions. The most apparent outcome of this crisis is a sharp decline in the number of tourists' arrivals in Egypt. To cope with this decline, the local hospitality industry increases its reliance on the domestic market by offering a variety of package deals. And to cope with this decline, the hotel management used many practices to face this situation, the decrease in foreign visitors is compensated for by an increase in domestic tourism, resulting in a change of consumer proportions. As a result, while in 2010, the number of arrivals was 14 million, the number turned down in the next years to be the lowest in 2016 by 5.3 million arrivals.

\section{Objectives of the study}

- To explore the main training and development methods used in the Egyptian hotels

- To identify the impact of training and development on manager's awareness of crises management. 


\section{Literature review}

\section{The concept of crisis management}

Crisis management is defined by Susana (2017) as "A systematic attempt by an organization and its stakeholders to manage or prevent crises from occurring, such that key stakeholders believe the success outcomes outweigh the failure outcomes".

Moreover, literature has accommodated two different viewpoints regarding crisis management. One group of scholars argued that crises are recurring and not preventable (Faulkner, 2018).; whereas others contended that there are ways through which organizations can prevent, manage, or mitigate the effects of crises (Nikolaos, 2018).

Nowadays, crisis management has become an essential part of all kinds of businesses (Basurkina, 2017). And latest since the $9 / 11$ terrorist attacks in New York and Washington, crisis management has become an important part of the hospitality industry (Barton, 2008). It is an effective management tool to get to know what kind of threats there are to a business and helps to anticipate the threats for a quick response and to control the damage to the business (Abd ElZaher, 2019).

According to Marketa et. al., (2019), the terrorist attacks of 9/11 had a considerable impact on hospitality and tourism services. Since tourism is often seen as a discretional consumer good, it tends to be more affected by adverse economic conditions than other sectors (Song \& Lin, 2010). The conventional view is that shocks (crises) are damaging the industry's revenue. Since hotel expenses make up the largest portion of tourist expenditure, it is expected for hotel companies to feel such impact, reflected in hotel occupancy, rates, and overall hotel performance (Hsieh et al., 2013).

\section{Reasons for carrying out training and development}

According to FALOLA et al. (2014), training and development are indispensable strategic tools for effective individual and organization performance, thus, organization is spending money on it with confidence that both will earn them a competitive advantage in the world of business, However, for any organization to achieve its stated goals and objectives in this competitive world, adequate and relevance training and development of staff cannot be overemphasized (Birdi et al., 2008). Organization is expected to identify the training need of its employees and design training programs that will help to optimally utilize their workforce towards the actualization of organization objectives (Weil et al., 2005). Training and development are techniques used to transfer the employee's relevant skills, knowledge, and competence to improve their performance on current jobs and future assignments. It is not negotiable for organizations to adequately train their employees for efficient and optimal performance toward the realization of their set goals and objectives (Kennedy et al., 2013).

\section{Importance of employee development}

Naveed et. al. (2014) stated that employees are the most valuable resources of every organization because a clever work without human resources is not possible getting these things. So, every organization is spending huge money in training and development.

To achieve the organization's goals, human resources plays an important in terms of organizational growth and development. Basically, human resources are related to training, if your employee is trained, he/she can better perform in organizations (Weil \& Woodall 2015). Organizations should have focused more on training than on cost control and efficiency because an organization cannot get effectiveness without training and development (Alao, 2010). 


\section{Training and development programs}

According to Raja et al. (2011), the organization must design the training very carefully. The design of the training should be according to the needs of the employees. (Armstrong, 2000). Those organizations which develop a good training design according to the need of the employees as well as to the organization always get good results. It seems that training design plays a very vital role in the employee as well as organizational performance. Bad training design is nothing but the loss of time and money (Tsaur and Lin, 2004).

\section{Types of training}

Orientation to New Jobs or Roles

According to Benedicta (2010), orientation to New Jobs is given to newly hired employees to induct them into the organization and train them on the job they will hold. The employees are taught the culture, values, mission and processes and activities followed in the organization.

A carefully developed procedure for orienting new employees is very helpful for getting employees "off on the right foot" when starting their jobs (Shamim et al., 2013).

On-the-job methods

Management education normally takes place off the job, but a great deal of learning takes place on the job. Managers learn most from assignments that are very difficult and challenging. A program of management education should include assignments and job rotation plans that stretch managers to their limits (Grobler et al., 2004).

According to Shamim et al. (2013), Joseph (2009), (Grobler et al., 2006) and (Franklin, D, et al., 2014), understudy assignments, coaching, job rotation, special projects and committee assignments, apprenticeships and internships are some of the on-job training methods provided in organizations.

Off-the-job methods

According to Kreitner and Kinicki (2007), Bassanini (2004), JOSEPH (2009), Ruth \& Doug (2004), Franklin et al, (2014) and Shamim et al. (2013), off-the-Job training is the training technique wherein the workers/employees learn their job roles away from the real work floor.The following are some of the off-the-job training methods provided in organizations:

classroom training, lectures, computer-based training, games and simulation, university and professional association seminars, career counseling, courses, and distance learning.

\section{Research methods}

\section{Population and sample}

The current study is based on a quantitative-qualitative approach to achieve its aim. Data collection technique for the study will be a Semi-structured questionnaire to collect data from different head department managers at four \& three-star hotels in Cairo and Sharm El Sheikh which counted to 172 hotels Egyptian Hotel Guide (2017). Obtained data will be analyzed using SPSS version 22. The population of the study is the managers who counted (1548 nearly ) about 9 H.O.D`s in each hotel, The Central Agency for Public Mobilization and Statistics, (2017). So according to Khalifa and Ali (2017), the sample will be calculated according to the following formula:

$\mathrm{N}=$ Study Population $=1548$

$\mathrm{Z}=0.95=1.96$

$\mathrm{d}=0.05$

$n=\frac{N \times p(1-p)}{\left.\left.\llbracket N-1 \times\left(d^{2} \div z^{2}\right)\right]+p(1-p)\right]^{\times N}}$

$\mathrm{p}=0.50$

$\mathrm{n}=387$ 
The study sample was conducted on a total of 24 hotels (twenty from four-star hotels and twentythree from three-star hotels in Greater Cairo City and Sharm El Sheikh City. The sample was chosen based on the following inclusion criteria:

1. The category of the hotel must be four or three-star.

2. The facility must be in Greater Cairo or Sharm El Sheikh City.

Greater Cairo and Sharm El Sheikh City have been chosen as the prime case study area because:

1. It is the most dominant social, political, economic, etc. center in Egypt.

2. According to the Chamber of Tourist Establishments (2017) and Egyptian Hotel Association (2017), Greater Cairo City and Sharm El Sheikh City include the biggest number of hotels in Egypt.

The total number of the questionnaire was 450 copies, distributed on four $\&$ three-star hotels H.O.D. `s. or/and assistants as a random sample, 400 were returned. The response rate reached $89 \%$.

The researcher selected a sample of 400 four \& three-star hotels H.O.D.`s. or/and assistants for more validity. The study used a semi-structured questionnaire for data collection. A modified questionnaire was designed to explore the levels of knowledge, attitudes, and practices among the head of departments or/and assistants that have a crisis effect on hotels' operation in Great Cairo and Sharm El sheikh. An investigation of developing H.O.D.'s or/and assistant's performance in case of crisis and catastrophes were carried out using multiple sources of data, including a semi-structured questionnaire, observations of the business environment, and a review of documentation.

A questionnaire form was designed and distributed to the head of departments or/and assistances in the selected sample during the period between September 2019 - January 2020.

\section{Testing Validity and Reliability}

Cronbach's Alpha Coefficient is used, which should have a value equal to or greater than (0.7).

Table 1: Reliability analysis for Sub domains

\begin{tabular}{|l|l|l|l|}
\hline Variable & No. items & Reliability & Validity \\
\hline CMP concept and Functions & 6 & 0.747 & 0.864 \\
\hline CMP Effects and Benefits & 15 & 0.895 & 0.946 \\
\hline Practices may use in case of crisis & 17 & 0.710 & 0.846 \\
\hline
\end{tabular}

The results show that the questions have a Validity and reliability which exceeded (0.70) for all respondents.

\section{Questionnaire Design}

The questionnaire was made up of three parts. The first part collected demographic information from the respondents. The second part examined the awareness of crisis management plan concepts and functions according to Jie (2018), Gamal et. al. (2017), Susana et.al. (2017) and Ozdemir (2016) using a Likert scale of 1-less important to 5-most important. The third part examined the training and development methods which apply and the level of actual use for each method according to Falola (2014), Raja (2011) and Alao (2010) using the same Likert scale ranging from 1-extensively used to 5-rarely used.

The questionnaire was sent to 450 participants who included middle-level managers, department heads and other senior managers of different $3 \& 4$-star hotels in Cairo and Sharm El Sheikh. Responses were received from 400 participants. The sample group demographics are presented in table 2 . The majority were men. ages ranged between 20 and 40, and all of them held management positions. 
The study has two main hypotheses for analyzing crisis management.

H1: There is a positive significant statistical relationship between the Methods which applied to develop the performance and the H.O.D.`s awareness about the concept and functions of CMP

H2: There is a positive significant statistical relationship between the Methods which applied to develop the performance and the respondents' awareness about the effects and benefits of CMP.

Table 2: No. of hotels in Cairo and Sharm El Sheikh

\begin{tabular}{|l|l|l|l|l|}
\hline Hotels category & Cairo & Sharm El Sheikh & Egypt & Cairo + SHH in Egypt \% \\
\hline $5 *$ & 33 & 41 & 153 & $48.4 \%$ \\
\hline $4 *$ & 18 & 62 & 199 & $40.2 \%$ \\
\hline $3 *$ & 40 & 52 & 256 & $36 \%$ \\
\hline $2 *$ & 34 & 22 & 174 & $32.2 \%$ \\
\hline $1 *$ & 26 & 4 & 106 & $28.3 \%$ \\
\hline $\begin{array}{l}\text { Under } \\
\text { classification }\end{array}$ & 5 & 10 & 71 & $21.1 \%$ \\
\hline Total & 156 & 191 & 959 & $36.2 \%$ \\
\hline
\end{tabular}

Source: Egyptian Hotels Association Guide, (2017)

\section{Results}

Table 3: Descriptive statistics of the respondents

\begin{tabular}{|l|l|l|}
\hline Variable & Frequency No(n=450) & Percent \% \\
\hline Gender & & \\
\hline Male & 391 & 97.8 \\
\hline Female & 9 & 2.3 \\
\hline Age & & \\
\hline $20: 30$ & 45 & 11.3 \\
\hline $30: 40$ & 212 & 53.0 \\
\hline $40: 50$ & 108 & 27.0 \\
\hline $50: 60$ & 34 & 8.5 \\
\hline$>60$ & 1 & .3 \\
\hline Hotel Area & & \\
\hline Cairo & 139 & 34.8 \\
\hline Sharm & 261 & 65.3 \\
\hline Category: & & \\
\hline 3 stars & 220 & 55.0 \\
\hline 4 Stars & 180 & 45.0 \\
\hline According & & \\
\hline
\end{tabular}

According Table 3:

1- Most of respondents were males (97.8\%) and very few were females (2.3\%) which means that the hotels field not attracted for the female employees or there are not continued to be a manager.

2- Most of respondents ages between 30 to less than 50 years old 30:40 (53\%) followed by 40:50 (27\%) and very few over 50 years old (8.8\%) which means that the filed lost his experienced managers and also most of them changed their carrier before the fiftieth years' old.

Table (4): - Correlation co-efficient between methods which applied to develop the performance and the Awareness About Crises Management $(n=400)$ 


\begin{tabular}{|l|l|l|l|l|l|l|l|}
\hline Correlations & & $\begin{array}{l}\text { Total } \\
\text { Methods }\end{array}$ & $\begin{array}{l}\text { New employee } \\
\text { orientation } \\
\text { program }\end{array}$ & $\begin{array}{l}\text { Training } \\
\text { process }\end{array}$ & $\begin{array}{l}\text { On the job } \\
\text { training }\end{array}$ & $\begin{array}{l}\text { Off the } \\
\text { job } \\
\text { training }\end{array}$ & $\begin{array}{l}\text { Evaluating Training } \\
\text { and } \begin{array}{c}\text { Development } \\
\text { Effectiveness }\end{array}\end{array}$ \\
\hline $\begin{array}{l}\text { CMP Effects } \\
\text { and Benefits }\end{array}$ & $\mathrm{r}$ & 0.893 & 0.814 & 0.751 & 0.622 & 0.845 & 0.811 \\
\hline CMP concept & $\mathrm{p}$ & $<0.001 * *$ & $<0.001 * *$ & $<0.001 * *$ & $<0.001 * *$ & $<0.001 * *$ & $<0.001^{* *}$ \\
\cline { 2 - 8 } and Functions & $\mathrm{p}$ & $<0.001 * *$ & 0.723 & 0.678 & 0.627 & 0.804 & 0.765 \\
\hline
\end{tabular}

$* *$ Statistically Significant Correlation at $\mathrm{p}$. value $<0.01$

According to the table 4:

H1: there is a positive relationship that exists between all Training and Development methods on Managers Awareness About CMP concept and Functions ( $r=0.837$ ) and p. value $<0.01$

Also, there is a positive relationship between all Training and Development methods parts on Managers Awareness About CMP concept and Functions as shown:

Off the job training ( $\mathrm{r}=0.804)$ and $\mathrm{p}$. value $<0.01$, Evaluating Training and Development Effectiveness $(r=0.765)$ and $p$. value $<0.01$, New employee orientation program $(r=0.723)$ and $p$. value $<0.01$, Training process $(r=0.678)$ and $p$. value $<0.01$, On the job training $(r=0.627)$ and $p$. value $<0.01$.

H2: there is a positive relationship that exists between all Training and Development methods on Managers Awareness About CMP Effects and Benefits $(r=0.893)$ and $p$. value $<0.01$. Also there is a positive relationship between all training program and development methods parts on managers awareness about CMP effects and benefits as shown:

Off the job training $(\mathrm{r}=0.845)$ and $\mathrm{p}$. value $<0.01$, evaluating training and development effectiveness $(\mathrm{r}=0.811)$ and $\mathrm{p}$. value $<0.01$, New employee orientation program $(\mathrm{r}=0.814)$ and $\mathrm{p}$. value $<0.01$, Training process $(\mathrm{r}=0.751)$ and $\mathrm{p}$. value $<0.01$, On the job training $(\mathrm{r}=0.622)$ and $\mathrm{p}$. value $<0.01$

Table 5: Descriptive for the concept of crisis and crisis management plan of the study sample

\begin{tabular}{|l|l|l|l|}
\hline & Range & Mean & Std. Deviation \\
\hline $\begin{array}{l}\text { A crisis is any situation that has the potential to affect long-term } \\
\text { confidence in an organization or a product, or which may interfere } \\
\text { with its ability to continue operating normally. }\end{array}$ & $2-5$ & 3.888 & 0.742 \\
\hline $\begin{array}{l}\text { CMP is a tool to consider every kind of possibility and give advice } \\
\text { in case a crisis happens. }\end{array}$ & $2-5$ & 3.898 & 0.830 \\
\hline CMP is a tool for the quick response to a possible threat & $2-5$ & 3.815 & 0.805 \\
\hline CMP is a tool to organize the performance in case a crisis happens. & $2-5$ & 3.963 & 0.638 \\
\hline CMP is a tool to minimize losses or damages. & $3-5$ & 4.075 & 0.762 \\
\hline $\begin{array}{l}\text { it is a written document outlining the official procedures applying } \\
\text { in case of crisis }\end{array}$ & $3-5$ & 4.418 & 0.574 \\
\hline
\end{tabular}

According to Table (5), the concept (it is a written document outlining the official procedures applying in case of crisis) was highly Respond, followed by the concept (CMP is a tool to minimize the losses or damages), which agreed with (Jie, 2018), (Wang \& Ritchie, 2012) and (Hartmann,2011)

Table (6) explained the ranking of The Methods used to develop the performance from the higher to lowest with their means.

\begin{tabular}{|l|l|l|}
\hline & Mean & Std. Deviation \\
\hline Total Training process planning & 3.591 & 0.537 \\
\hline Total On the job training & 3.448 & 0.496 \\
\hline Total New employee Orientation program & 3.338 & 0.712 \\
\hline Total Off the job training & 2.622 & 0.7 \\
\hline
\end{tabular}




\begin{tabular}{|c|c|c|}
\hline Total Evaluating Training and Development Effectiveness & 2.117 & 0.949 \\
\hline 5/2- Tour of facilities & 4.075 & 0.852 \\
\hline 5/11- Job instruction training & 4.053 & 0.931 \\
\hline 5/8- Chose training methods & 4.045 & 0.748 \\
\hline 5/24- Programmed instruction & 3.91 & 0.946 \\
\hline 5/6- Set objectives for training & 3.813 & 0.78 \\
\hline 5/9- Conduct training & 3.778 & 0.98 \\
\hline $5 / 3$ - Involvement of co-workers & 3.718 & 0.905 \\
\hline 5/14- Coaching & 3.708 & 1.098 \\
\hline 5/5- Assess training needs & 3.668 & 0.65472 \\
\hline 5/7- Decide who will participate & 3.66 & 1.043 \\
\hline 5/22- Classroom training & 3.538 & 1.171 \\
\hline 5/13- Apprenticeships & 3.183 & 0.928 \\
\hline 5/18- Role playing & 2.938 & 0.967 \\
\hline 5/25- Laboratory training & 2.92 & 1.18 \\
\hline 5/15- Lectures & 2.855 & 1.378 \\
\hline 5/12- Job rotation (Cross-training) & 2.85 & 0.877 \\
\hline 5/1- Employee handbook & 2.788 & 1.265 \\
\hline 5/4- Follow up & 2.77 & 0.818 \\
\hline 5/10- Evaluate training (pretest, posttest $\&$ follow up) & 2.583 & 0.946 \\
\hline $5 / 20$ - Simulation & 2.495 & 1.208 \\
\hline 5/26- Business games & 2.38 & 0.907 \\
\hline 5/17- Vestibule training & 2.375 & 1.11 \\
\hline 5/28- Pre- training performance method & 2.263 & 1.167 \\
\hline 5/16- Video presentation & 2.183 & 0.983 \\
\hline 5/31- Pre-post- training performance with control Group method & 2.18 & 0.998 \\
\hline 5/23- In-basket technique & 2.178 & 0.904 \\
\hline 5/21- Understudy assignments & 2.16 & 1.073 \\
\hline 5/19- Case studies & 2.123 & 0.956 \\
\hline 5/29- Post- training performance method & 2.058 & 1.003 \\
\hline 5/27-.University and professional association seminars & 2.003 & 0.975 \\
\hline 5/30- Pre-post- training performance method & 1.968 & 1.039 \\
\hline
\end{tabular}

According to Table 6, the most Methods used to develop the performance is (Tour of facilities) with a mean (4.075), followed by (Job instruction training) with a mean (4.053), followed by (Chose training methods) with a mean (4.045), The Method used to develop the performance (Pre-post- training performance method) seemed the least important factor with a total mean (1.968).

On the other hand, table 6 shows that the most Methods group used to develop the performance is (Training process planning methods) with a mean (3.591), followed by (On the job training methods) with a mean (3.448), followed by (New employee Orientation program methods) with a mean (3.338) ), followed by (Off the job training methods) with a mean (2.622) and (The Evaluating of Training and Development Effectiveness methods ) seemed the least important factors with a total mean (2.117), which agreed with Benedicta (2010), (Shamim et al. 2013), Raja et. al. (2011), (Grobler et al. 2004), Abu-Baker, M. (2010), Franklin, D, et al. (2014), (Smit and de Cronje,2003), (Perry. 2007), Kreitner et al. (2007) and Anderson (2003). 


\section{Conclusion and limitations}

This study investigated the methods to develop the performance used in the Egyptian hotels' industry and the Awareness About Crises. The study has tested two hypotheses of how these factors (CMP concept and functions awareness,) \& (CMP Effects and Benefits awareness) affecting the dependent variable (methods to develop the performance which used). The study has used a questionnaire to collect data from 400 Managers to perceive their opinions on the factors affect Egyptian hotels. The study has revealed very useful results in the way it evaluated the perceptions of managers on the hotels and described the factors that hotels have succeeded to offer in their CMP. Meanwhile, the study has provided hotel managers with some feedback on the overall perception of their CMP and the training methods better to use. The study has indicated that Most of the respondents in booth Cairo and SSh indicated that the most methods may use is (On the job training), followed by (New employee Orientation program), followed by (Off the job training), which means that on the job training is the main method which used and effect the awareness about CMP

\section{Research recommendations}

According to the study results, the following recommendations could be suggested the following:

- The need to continue holding training courses for hotels workers on how to deal with crises

- The need to prepare a training program for all new hiring and newly promoted employees including orientation, on the job, off job and evaluation tools.

- The need to making training centers to offer hospitality courses which accepted from the ministry of tourism, Egyptian Hotels Association and labor force office

- The need to prepare cooperation protocols between the hotels and hotel management faculties to train the students in the hotels and employees in the faculties

\section{References}

Abd El- Zaher, Samar Nabil Khalaf, (2019) Crisis Management of Food Rumors and Its Impact on The Purchasing Decision of the Local Restaurant Customers in Fayoum City, Ph.D. thesis, Faculty of Tourism and Hotels Department of Hotel Studies, Fayoum University

Alao, B.S. (2010) The Impact of Training and Development on Employees Performance: A Case study of Nigerian Bottling Company. A B.Sc. Research Project: Faculty of Business and Social Sciences, University of Ilorin

Alonso-Almeida, M. D. M., Bremser, K., \& Llaeh, J. (2015). Proactive and reactive strategies deployed by restaurants in times of crisis: Effects on capabilities, organization and competitive advantage. International Journal of Contemporary Hospitality Management, 27 (7). 1641-1661.

Bassanini, A. (2004). Improving Skills for More and Better Jobs? The Quest for Efficient Policies to Promote Adult Education and Training. paper presented at the European Commission Conference on Quality and Efficiency in Education, Brussels, May.

Birdi, K., Clegg, C., Patterson, M., Robinson, A., Stride, C. B., Wall, T. D., Wood, S. J. (2008). The impact of human resource and operational management practices on company productivity: a longitudinal study. Personnel Psychology, 61(3), 467-501.

Candemir, A., \& Zalluhoglu, A. (2011). The effect of marketing expenditures during financial crisis: The case of Turkey. Procedia Social and Behavioral Studies, 24, 291-299.

Center, A. H., Jackson, P., Smith, S., \& Stansberry, F. R (2008). Public relations practices: Managerial case studies and problems. Pearson Prentice Hall 
Chen, M.-H. (2011). The response of hotel performance to international tourism development and crisis events. International Journal of Hospitality Management, 30(1), 200-212.

Chong, I. K. (2004). Six steps to better crisis management. Journal of Business Strategy, 25(2), 43-46.

Coombs, W. T., \& Holladay, S. J. (2002). Helping crisis managers protect reputational assets: Initial tests of the situational crisis communication theory. Management Communication Quarterly, 16(2), 165-186.

Crandall, W. R., Parnell, T. A., \& Spillan, J. E. (2013) Crisis management: Leading in the new strategy landscape. Sage Publications.

Dirk Glaesser, (2006). Crisis Management in the Tourism Industry, Elsevier, Great Britain.

Duke, C.R., Persia, M.A., 1996. Performance-importance analysis of escorted tour evaluations. In: Fesenmaier, D.R., O’Leary, Uysal, M. (Eds.), Recent Advances in Tourism Marketing Research. The Haworth Press, London.

Eugenio-Martin, J. L., \& Campos-Soria, J. A. (2014). Economic crisis and tourism expenditure cutback decision. Annals of Tourism Research, 44, 53-73.

Falk, M. (2013) A survival analysis of ski lift companies. Tourism Management, 36, 377-390.

Falola, H. O., Osibanjo, A. O., Ojo. S. I. (2014). Effectiveness of training and development on employee's performance and organization competitiveness in the Nigerian Banking industry, Bulletin of the Transilvania University of Braşov Series V: Economic Science, 7(56), 161170.

Gamal S. A. Khalifa and EL-Hussin M.S. Ali (2017). Managing drivers and boundaries of information technology risk management (ITRM) to increase Egyptian hotels market share| International Journal on Recent Trends in Business and Tourism. Vol. 1 (1) January 2017

Hart, P., Heyse, L., \& Boin, A. (2001) New trends in crisis management practice and crisis management research: Setting the agenda. Journal of Contingencies and Crisis Management, 9(4),181-188.

Hernandez, J. R. (2015). How do managers handle organizational rumors effectively, and does emotional intelligence help? A qualitative inquiry (Doctoral dissertation, Capella University).

Hartmann, Jana. (2011) Crisis Management of the Hotel Industry in Finland, Bachelor Thesis, HAAGA-HeLIA University of Applied Sciences.

Israeli, A.A. \& Reichel, A. (2003) Hospitality crisis management practices: The Israeli case. Int. J. Hospitality Management, 22(4), 353-372.

Jia, Z., Shi, Y., Jia, Y., \& Li, D. (2012). A framework of knowledge management systems for tourism crisis management. Procedia Engineering, 29, 138-143.

Kennedy, P.E, Chyung, S.Y, Winiecke, D.J., Brinkerholff, R.O. (2014). Training professionals' usage and understanding of Kirkpatrick's Level 3 and Level 4 evaluations. International Journal of Training and Development, 18(1), 1-21.

Kovoor-Misra, S., Clair, J., Bettenhausen, K., (2001). Clarifying the attributes of organizational crises. Technological Forecasting and Social Change 67, 77-91.

Marketa Kubickovaa \& Destan Kirimhanb, Hengyun Lic. (2019). The impact of crises on hotel rooms' demand in developing economies: The case of terrorist attacks of 9/11 and the global financial crisis of 2008. Journal of Hospitality and Tourism Management, 38, 27-38 
Mitroff, 1. 1. (2005) Why some companies emerge stronger and better from a crisis: 7 essential lessons for surviving disaster. AMACOM/American Management Association.Martilla, J., James, J., 1977. Importance-performance analysis. Journal of Marketing 4, 77-79.

Mitroff, I. I., C. M. Pearson, and L. K. Harrigan. (2001). The essential guide to managing corporate crises: A step-by-step handbook for surviving major catastrophes. New York: Oxford University Press.

Mitroff, II, \&Anagnos, G 2001, 'Managing Crises Before They Happen: What Every Executive and Manager Needs to Know About Crisis Management,' American Management Association.

Naidoo, P., Ramseook-Manhurun, P., \& Seetaram, A. K. (2010). Marketing the hotel sector in economic crisis: Evidence from Mauritius. Global Journal of Business Research, 5(2), 1-12.

Naidoo, V. (2010). Firm survival through a crisis: The influence of market orientation, marketing innovation and business strategy. Industrial Marketing Management, 39(8), 1311-1320.

Naveed Ahmad, Nadeem Iqbal, Maryam Sohail Mir, Zeeshan Haider, Naqvi Hamad. (2014). Impact of training and development on employee's performance A case study from different banking sectors of north Punjab. Arabian Journal of Business and Management Review (Nigerian Chapter), 2, (4),19-24.

Nikolaos Pappas. (2018) Hotel decision-making during multiple crises: A chaordic perspective. Journal of Tourism Management 68, 450-464

Okumus, F., \& Karamustafa, K. (2005). Impact of an economic crisis: Evidence from Turkey. Annals of Tourism Research, 32(4), 942-961.

Ozdemir, L. (2016). The Positive and Negative Effects of Crisis on Organizations: $A n$ Application, 4(1).

Paula MadalinaCretu\& Jonathan Puentes, (2010). Managing Organizational Crises in the Light of Political Unrest, The "Gulf Agency Company" Egypt Case, Master of Science in Business Administration Strategy and Management in International Organizations, Linköping, Sweden.

Pearson R.G., Raxworthy C.J., Nakamura M., Peterson A. Townsend. (2007). Predicting species distributions from small numbers of occurrence records: a test case using cryptic geckos in Madagascar J. Biogeogr., 34, 102-117.

Ritchie, B. (2008). Tourism disaster planning and Management: From response and recovery to reduction and readiness. Current Issues in Tourism, 11(4), 315-348.

Raja Abdul Ghafoor Khan, Furqan Ahmed Khan, Muhammad Aslam Khan (2011). Impact of Training and Development on Organizational Performance, Global Journal of Management and Business Research, 11(7).

Ritchie, B. (2008). Tourism disaster planning and Management: From response and recovery to reduction and readiness. Current Issues in Tourism, 11(4), 315-348.

Seeger, M. W., Ulmer, R. R., Novak, J. M., \& Sellnow, T. (2005). Post-crisis discourse and organizational change, failure and renewal. Journal of Organizational Change Management, 18(1), 78-95.

Seeger, MW, Sellnow, TL, \& Ulmer, RR (2003). Communication and Organizational Crisis, Preager Publishers.

Sheppard, B.H., Hartwick, J., Warshaw, P.R. (1988). The theory of reasoned action: a metaanalysis of past research with recommendations for modifications and future research. Journal of Consumer Research 15, 325-343. 
Smith, D, \& Elliot, D (2006). Key Readings in Crisis Management: Systems and Structures for Prevention and Recovery, Routledge Publishers.

Song, H., Lin, S., Witt, S. F., \& Zhang, X. (2011). Impact of financial/economic crisis on demand for hotel rooms in Hong Kong. Tourism Management, 32(1), 172-186.

Sönmez, S.F., Apostolopoulos, Y., Tarlow, P., (1999). Tourism in crisis: managing the effect of terrorism. Journal of Travel Research, 38, 13-18.

Sönmez, S.F., Backman, S.J., Allen, L.R., 1994. Managing Tourism Crises: A Guidebook. Department of Parks, Recreation, and Tourism Management, Clemson University, Clemson, SC.

Susana Cro, Antonio Miguel Martins. (2017). Structural breaks in international tourism demand: Are they caused by crises or disasters? Journal of Tourism Management, 63, 3-9.

Tsaur, S.H., Lin, Y.C. (2004). Promoting service quality in tourist hotels: the role of HRM practices and service behavior, Tourism Management, 25(4), 471-481.

Ukakturk, A., Bekmenzci, M., \& Ukakturk, T. (2011) Prevailing during periods of economic crisis and recession through business model innovation. Procedia: Social and Behavioral Studies, 24, 89-100.

Wang, J., \& Ritchie, B. W. (2012) Understanding accommodation managers' crisis planning intention. An application of the theory of planned behavior. Tourism Management, 33(5), 1057-1067.

Weil, A., Woodall, J. (2005). HRD in France: the corporate perspective. Journal of European Industrial Training, 29 (7), 529-540.

WTTC, (2018). World Travel \& Tourism Council, Economic Impact Reports. 